\title{
Glacitectonic deformations in East Greenland
}

\author{
SVEND FUNDER AND KAJ STRAND PETERSEN
}

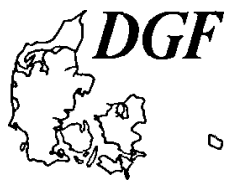

\begin{abstract}
Funder, S. \& Petersen, K. Strand: Glacitectonic deformations in East Greenland. Bull. geol. Soc. Denmark, vol. 28, pp. 115-122. Copenhagen. February 22nd, 1980.

https://doi.org/10.37570/bgsd-1979-28-13

Dislocated Quaternary marine and glacilacustrine sediments are demonstrated at two localities in East Greenland. The deformations comprise thrust floes, overturned folds and tension fractures formed by glacier overriding in the Holocene. At one locality there is evidence of ponded drainage and pro- and subglacial deformation of unfrozen sediments. Glacitectonic deformations have not earlier been recorded from Greenland.
\end{abstract}

S. Funder, Geologisk Museum, Øster Voldgade 5-7, DK-1350 Copenhagen K, Denmark; K. Strand Petersen, Geological Survey of Denmark, Thoravej 31, DK-2400 Copenhagen NV, Denmark, August 15 th, 1979.

\section{Introduction}

The deformation of unconsolidated sediments and sedimentary rocks by glacier overriding is a well known feature in the formerly glaciated parts of the northern continents (e.g. Moran 1971; Banham 1975; Petersen 1978). The present paper describes two localities in East Greenland where unconsolidated sediments have been deformed by Holocene glacier readvances (fig. 1). The areas were surveyed in 1974 and 1975 (Funder \& Petersen 1977). The observations are of interest because, they were made in an area where a thick permafrost layer and glaciers of distinctly polar type have persisted until the present day. Studies of the outcrops were facilitated by the lack of vegetation, and the patterns of deformed layers could often be observed in three dimensions.

\section{Vestersletten}

\section{Sediment and structures}

The sequence of Quaternary sediments on Vestersletten, eastern Gauss Halvø, appears from fig. 2. Deformation is restricted to the lowermost unit consisting of finely laminated clay and silt with horizons of loose sand. These sediments occupy an area extending $5 \mathrm{~km}$ across the valley floor of Vestersletten and $2 \mathrm{~km}$ in a down valley direction; they are exposed in small rounded ridges and knolls rising 5-10 m above the valley floor.

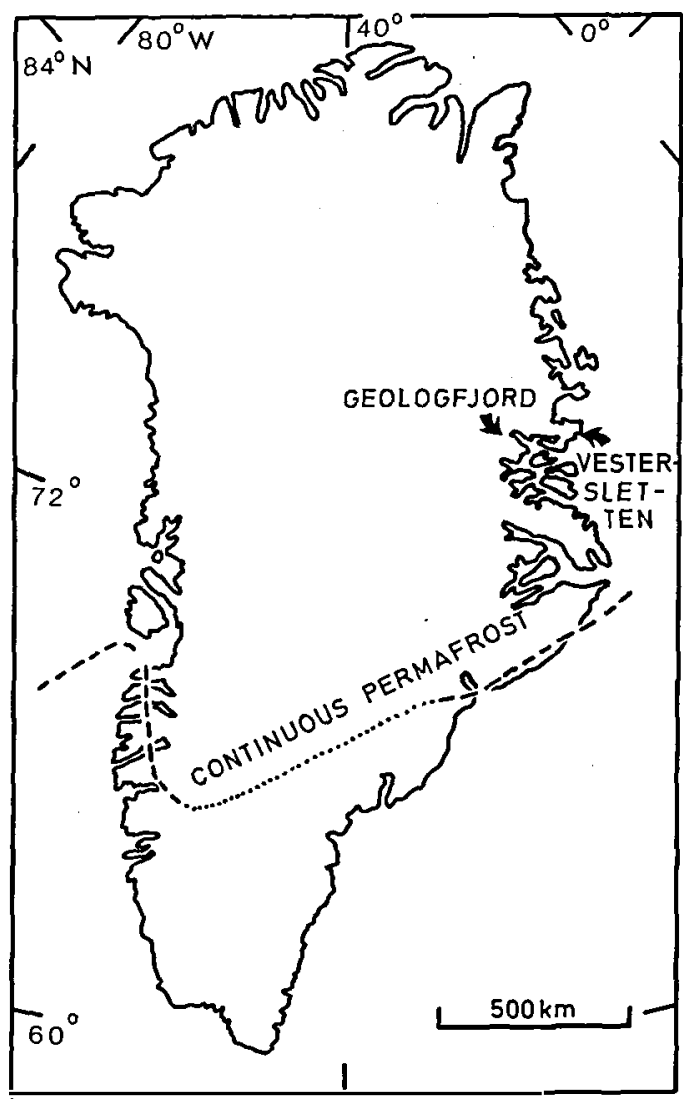

Fig. 1. The location of the two examples of glacitectonic deformations in relation to the present limit of continuous permafrost (after Weidick 1968). 


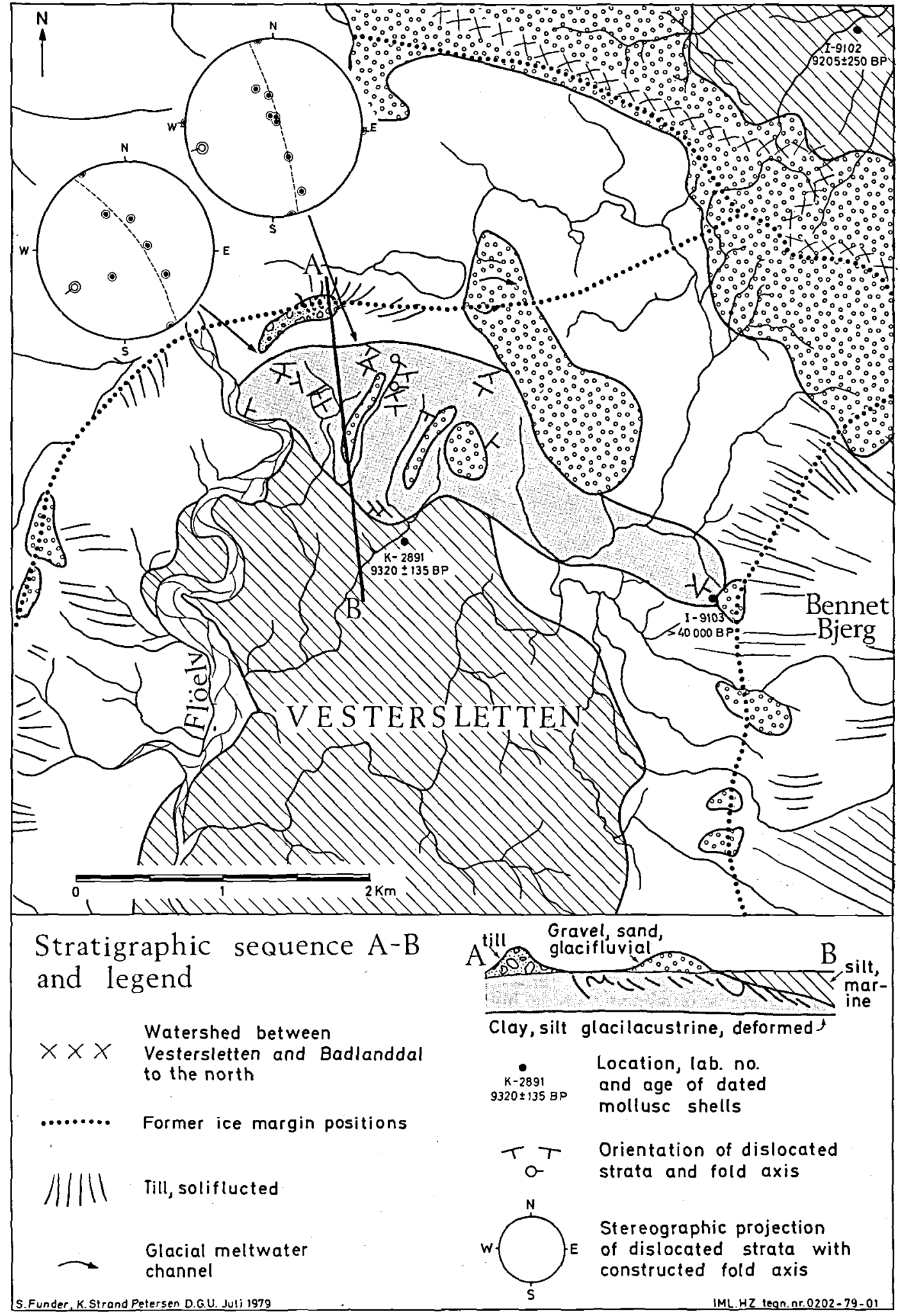

Fig. 2. The Quaternary geology of Vestersletten $\left(73^{\circ} 25^{\prime} \mathrm{N}, 21^{\circ} 49^{\prime} \mathrm{W}\right.$ ). Steographic projections (Wulffnet. lower hemisphere) of dislocated strata and the stratigraphic sequence. 

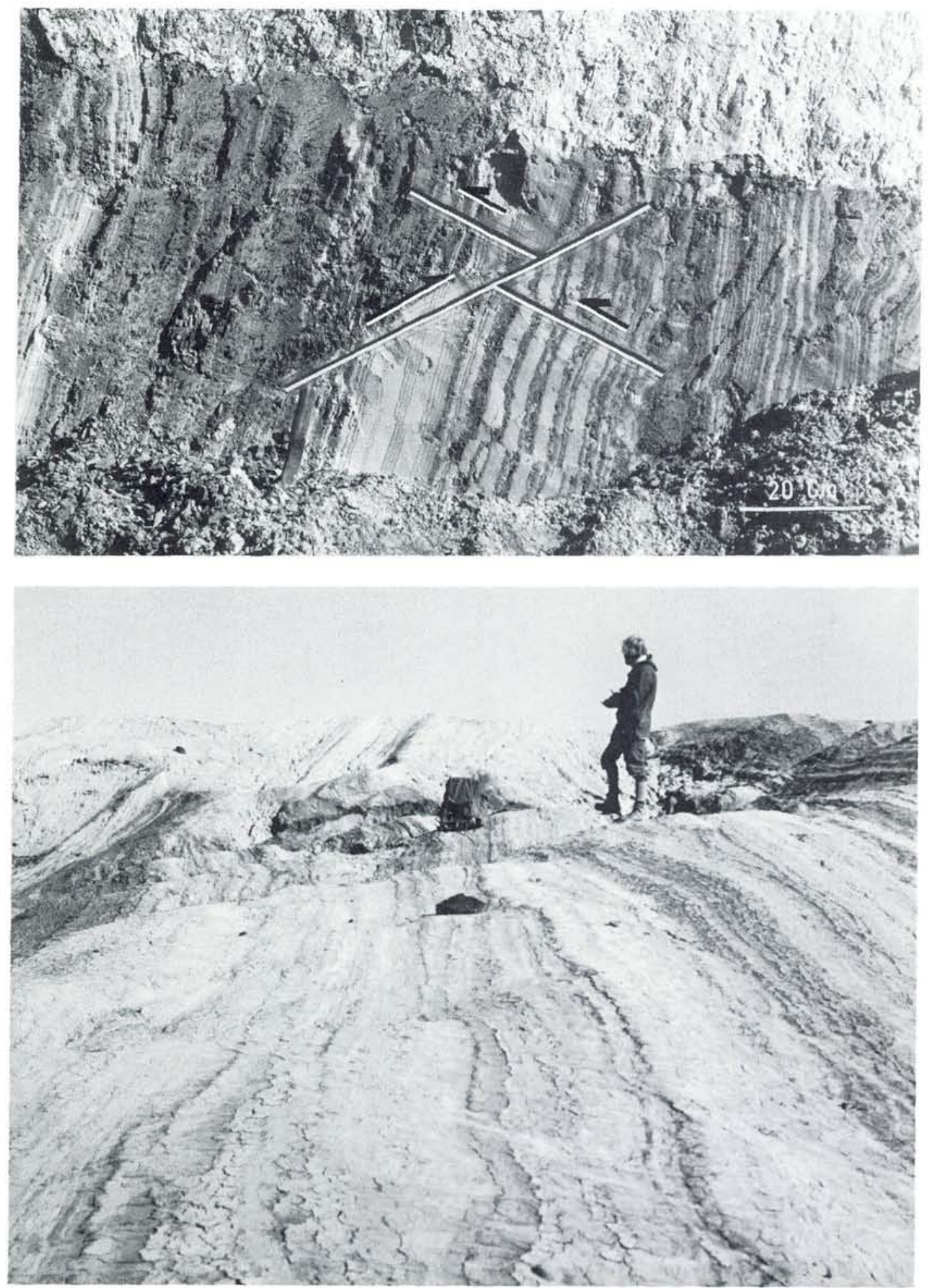

Fig. 3. The dislocated sequence of laminated clay and silt seen from the west exposed in roches moutonnées. Small scale reverse faults observed in the vertical profile by the person are depicted in the upper photo. 
They are devoid of vegetation, and in their concrete hard surface the complex patterns of deformed laminae are displayed (fig. 3).

The structures comprise imbricate thrust floes dipping down valley, and recumbent folds with fold axes more or less horizontal and parallel to the ice margin deposits crossing the valley (fig. 2). The folds are overturned in an up-valley direction and small scale reverse faults occur in the folded laminae (fig. 3). The folded sequence has a minimum thickness of $20 \mathrm{~m}$, but large parts of the structures have been removed by later glacial erosion. This erosion is also responsible for the roches moutonnées-like appearance of some of the knolls and the peculiar jointing, representing tension fractures (fig. 4, 5). The fractures appear as sets of fissures, appr. $50 \mathrm{~m}$ long and up to 0.5 $\mathrm{m}$ deep, parallel to the direction of the valley, and perpendicular to the topographic gradient; they are easily seen on the surface of the exposures, gouged out by wind-erosion (fig. 5).

The laminated sequence is considerably more fine grained than the later Holocene marine and glacimarine sediments in the area (fig. 6), and in lack of other evidence this feature, as well as the well developed lamination, suggest a glacilacustrine origin of the deformed sediments.

The coarsely bedded sand and gravel which overlie the laminated sequence to the north and along the valley sides are generally undisturbed. Channel fillings, current ripples and convolute structures have been observed in the sand and gravel sequence, which comprises kame terraces and glacifluvial deltas that flank the valley and indicate the presence of a glacier in the valley after the deformation of the laminated sediments had taken place. This evidence is corroborated by the patches of unsorted gravel and sand and scattered boulders lying on the deformed sediments in the central part of the valley, representing the remnants of a thin cover of melt out till. In this sediment reworked shells of Mya truncata and Hiatella arctica have given a $\mathrm{C}-14$ age of more than 40,000 years (sample I-9103), showing that old marine sediments once occurred in the vicinity.

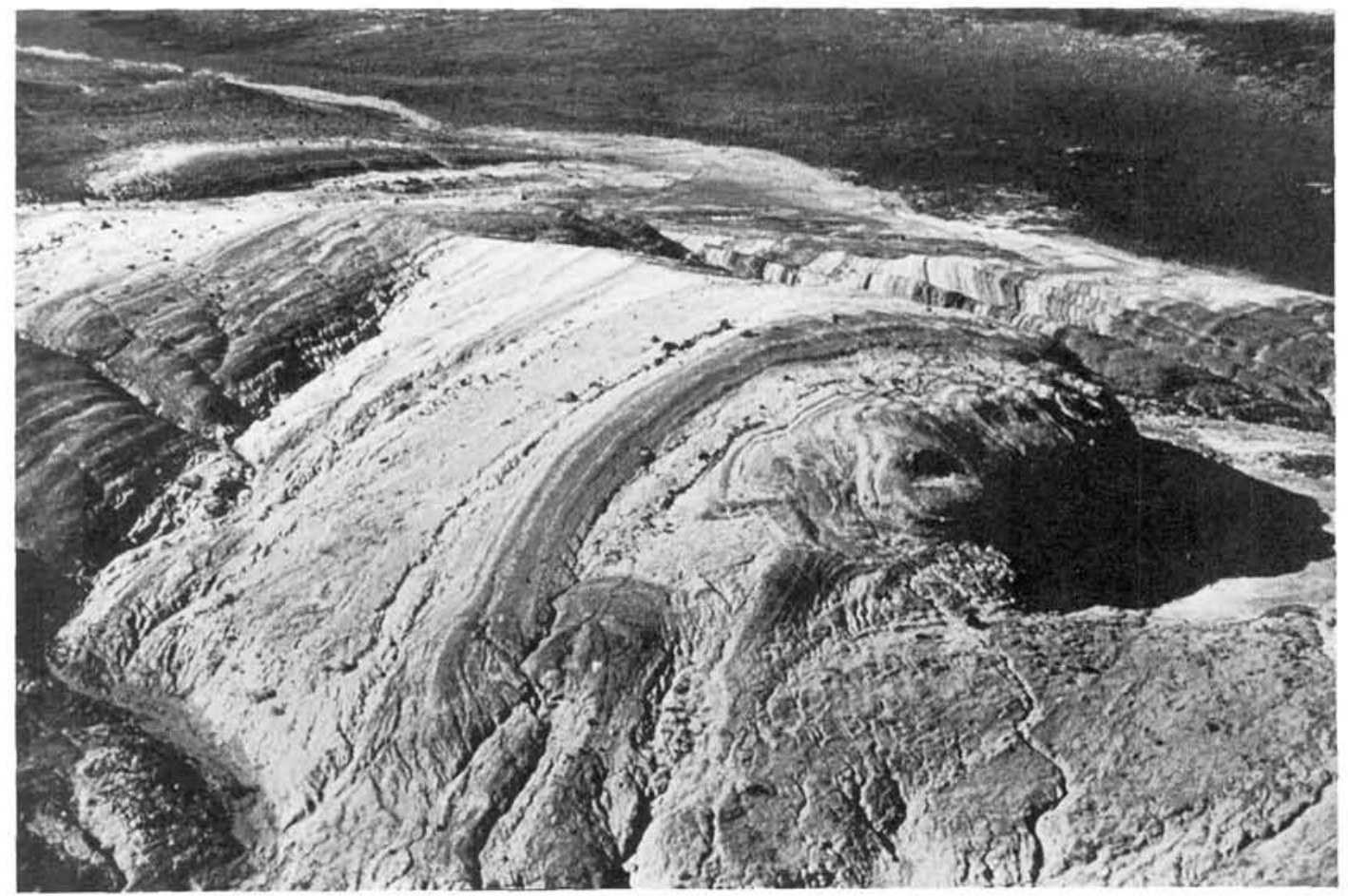

Fig. 4. The roots of the folded strata seen from the northeast oblique to the fold axis as they appear denuded by glacier overriding in the roches moutonnées like form. Tension fractures are seen in the background. The dark layers in the foreground have a thickness of $1 \mathrm{~m}$. Photo from a helicopter at about $10 \mathrm{~m}$ above the surface. 


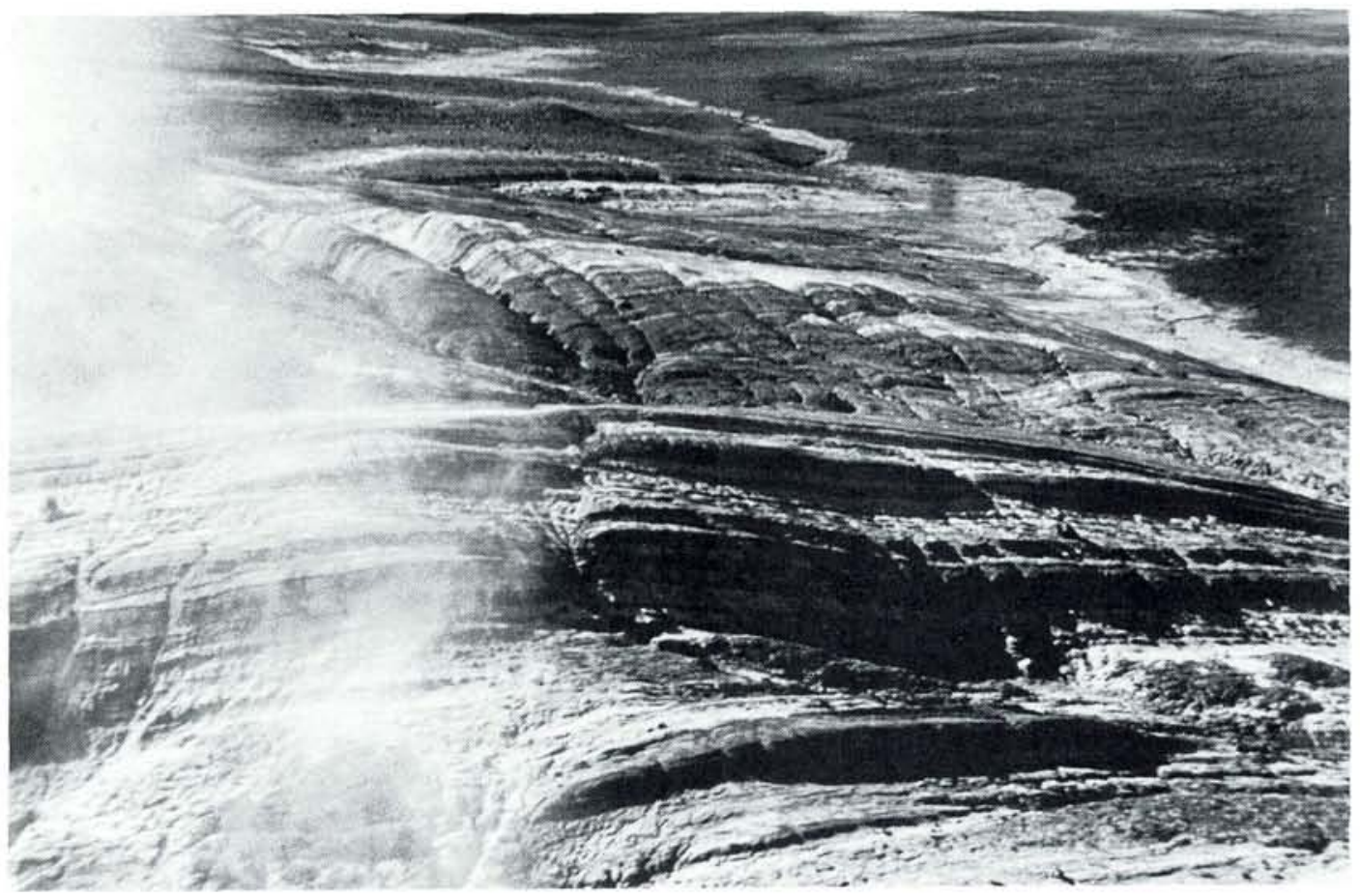

Fig. 5. Tension fractures same as in Fig. 4 background in the roches moutonnées seen from the north perpendicular to the fold axis. The helicopter, approximately $10 \mathrm{~m}$ above the surface, is agitating the fine grained sediment.

Deformation mechanism and implications

The general down-valley dip of inclined sediments and the up-valley overturn of folds suggest that the structures were formed by push and drag from a glacier moving up-valley from Kejser Franz Joseph Fjord in the south. That such a glacier movement did take place was shown already by Bretz (1935:170), and is attested by gla-

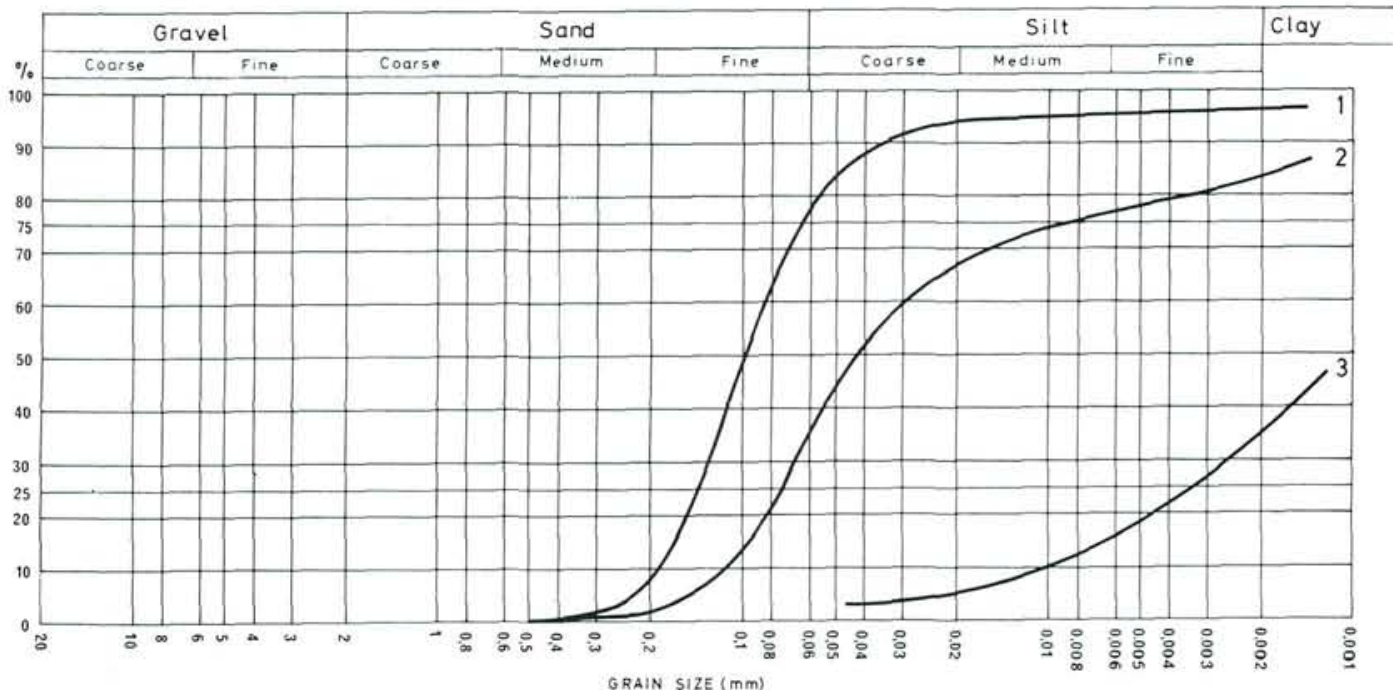

Fig. 6. Granulometric composition of the sediments in the Vestersletten area. 1 and 2 Holocene marine and glacimarine sediments. 3 glacilacustrine sediments from the deformed sequence. 
cial striations found up to $300 \mathrm{~m}$ above sea level on the adjacent Bennet Bjerg and by the gradients of moraines, melt water channels and glacifluvial deposits along the valley sides. Apparently the up-valley glacier movement terminated $1500 \mathrm{~m}$ to the north of the deformed sediments at the watershed now separating Vestersletten from the neighbouring Badlanddal to the north (fig. 2). In the latter valley at the same time a glacier moved in the opposite direction towards Kejser Franz Joseph Fjord.

The site on Vestersletten exhibits the features which have often been associated with glacitectonic deformation: up-slope ice movement, shallow ice cover, location near the ice margin, and rapid shifts between permeable and impermeable layers within the sedimentary sequence that would make it especially susceptible to deformation (Kupsch 1962; Moran 1971; Banham 1975). Thus Banham's »compressional model « of glacitectonic deformation apparently may apply to the observations on Vestersletten. In this model a fast up-slope ice advance causes ponded drainage and the development of excess pore

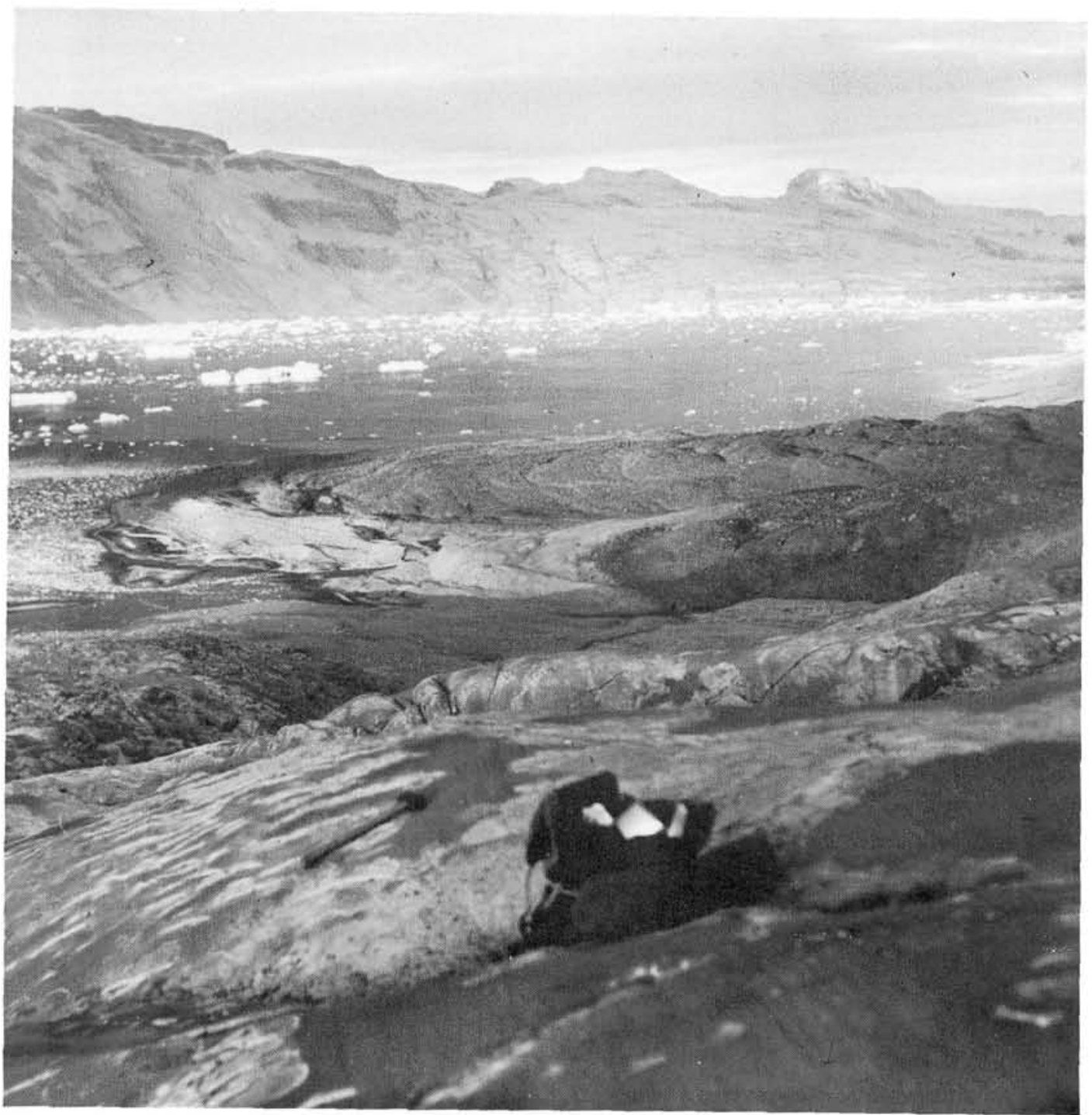

Fig. 7. Head of Geologfjord looking southeast. Rock glacier with concentric boulder ridges in the middle right. (Photo J. D. Friderichsen 1978). 
water pressure in unfrozen impermeable sediments. The folding and thrusting arise by the loading of these sediments owing to their reduced shear strength.

Of the tectonic features only the remnants are seen, as a large part of the structures have been removed, and tension fractures in the roches moutonnées were formed during the further advance of the ice when the site passed from a proglacial to a subglacial environment. The tension fractures were formed parallel to the direction of the glacier flow, i.e. parallel to the direction of the maximum stress.

The sequence of Quaternary sediments on Vestersletten is interpreted as reflecting the following events: (1) From the major fjord glacier in Kejser Franz Joseph Fjord a small tongue of ice branched off and moved up-valley over Vestersletten impeding the drainage in the valley. (2) An ice dammed lake was formed at the head of the valley, and more than $20 \mathrm{~m}$ of laminated clay, silt and sand were deposited in the lake. (3) The ice tongue advanced into the lake and the sediments were thrusted and folded. (4) During further advance of the glacier the structures were eroded and fractured. (5) The ice tongue retreated, and melt out till and thick piles of glacifluvial sediments were deposited over the deformed sequence. (6) As the ice tongue retreated, the valley system was transgressed by the sea, and marine sediments were deposited. Samples of shells from the marine sediments have been $\mathrm{C}-14$ dated to 9000-9100 yr BP, giving a minimum age for the disturbances.

\section{Geologfjord}

Near the head of Geologfjord, a small fjord leading into Kejser Franz Josephs Fjord (fig. 1), a small rock glacier has flowed down the steep fjord side and spread out to form a half circular protuberance in the fjord (fig. 7). The surface of this deposit is covered by locally derived boulders arranged in 1-2 $\mathrm{m}$ high concentric ridges. In the distal part of the "glacier snout " the boulder ridges rest on layered sand which forms the surface in the swallows between the ridges, and is exposed in the coastal cliff (fig. 8). In all exposures the sand layers are steeply inclined dipping

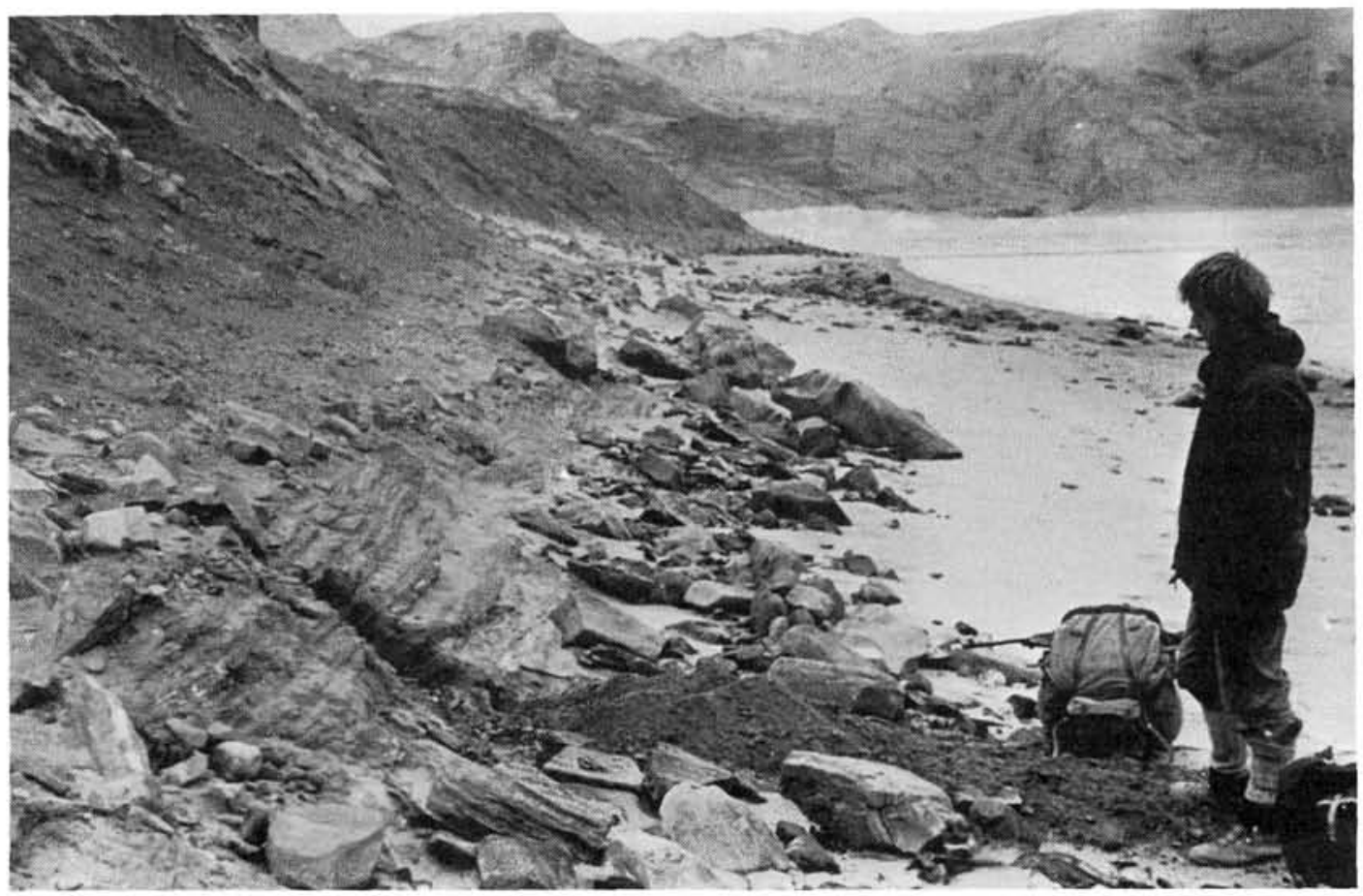

Fig. 8. The inclined marine beds as seen in the distal part of the rock glacier by the shore of Geologfjord. 
$30^{\circ}$ in an up-glacier direction and striking parallel to the concentric ridges.

The parallellism of the boulder ridges and the strike of the deformed sand layers show that the deformation took place along up-glacier dipping shear planes that extended through the rock glacier and into its substrate which was probably frozen at the time of deformation. Marine mollusc shells found in situ in the sand have given a C-14 age of 4240 yr BP (sample K-2419), providing a maximum age for the deformation.

\section{Discussion}

In the literature on glacitectonic deformations much attention has been given to the role of permafrost in the deformation process. It has frequently been suggested that high pore water pressure and low shear strength at the base of the permafrost layer provided a plane of décollement for the deformations. Hence the sediments were frozen when being deformed, their thickness reflecting the depth of permafrost (e.g. Kupsch 1962; Moran 1971; Berthelsen 1979).

The sites in East Greenland are situated well within the zone of continuous permafrost (fig. 1). Thicknesess of 80 and $220 \mathrm{~m}$ have been recorded for the permafrost at a site $150 \mathrm{~km}$ to the south (Kirchner 1963). If these values are regarded as minimum values for the depth of permafrost at the time when the sediments were deformed, it appears unlikely that the plane of décollement was determined by the thickness of the permafrost layer: the observed thickneses of the deformed sediments are much smaller, and the local topography seems to exclude the existence of sedimentary sequences with this thickness in the area. Hence the deformations probably occurred either along a plane of weakness within the permafrost, as may have been the case in the site in Geologfjord, or the sediments were unfrozen. Possibly the latter was the case at the site on Vestersletten where the body of water into which the sediments were deposited caused thawing of the permafrost surface, and the surface of the permafrost may have provided the plane of décollement.
Acknowledgements. This paper is published with the approval of the Director of the Geological Survey of Greenland. Stuart Watt (Geological Survey of Greenland) kindly improved the English of the text. We express our gratitude to Ella Hoch (Geological Museum) for a critical reading of the manuscript and to Asger Berthelsen (Geological Institute) and Leif Aabo Rasmussen (Geological Survey of Denmark) for discussions.

\section{Dansk sammendrag}

Dislocerede Kvartær lagserier beskrives fra to lokaliteter i Østgrønland. De deformerede sedimenter er ler, silt og sand af glacilacustrin og marin oprindelse. Deformationerne omfatter opskudte flager, liggende folder og tensionssprakker dannet ved gletscherfremrykning i Holocæn. På den ene lokalitet, Vestersletten, udgøres blotningerne af vegetationsløse roches moutonnées, hvor man i den cementhårde overflade ser lagenes rumlige konfiguration. Deformationerne her kan forklares ved »kompressions modellen«, der forudsatter gletscherbevægelse mod stigende terræn og opstemning af et grundvandspejl foran gletscheren. Den proglaciale opfoldning efterfulgtes af subglacial erosion, hvorunder tensionssprækkerne og de karakteristiske roches moutonnées former dannedes. På den anden lokalitet, Geologfjord, vises hvorledes en blokgletscher har deformeret frosne marine sedimenter langs shearplaner haldende mod gletscheren. Sidstnæunte deformationer menes at være sket langs svaghedszoner i de permafrosne lag. På Vestersletten antages opfoldningen at være sket over permafrostlaget.

\section{References}

Banham, P. H. 1975: Glacitectonic structures: A general discussion with particular reference to the contorted drift of Norfolk. In Wright, A. E. \& Moseley, F. (edit.) Ice ages: Ancient and modern. Geological Journal Special Issue 6, 69-95.

Berthelsen, A. 1979: Recumbent folds and boudinage structures formed by subglacial shear: an example of gravity tectonics. In: W. J. M. van der Linden (ed): Van Bemmelen and his search for harmony. Geol. Mijnbouw 58 (2).

Bretz, H. 1935: Physiographic studies in East Greenland. In Boyd, L. A. (edit.) The fiord region of East Greenland. Spec. publs Am. Soc. 18, 159-245.

Funder, S. \& Petersen, K. Strand 1977: Glacialgeologiske noter fra Østgrønland. Dansk geol. Foren., Arsskrift for 1976, p. 91.

Kirchner, G. 1963: Observations on bore holes sunk through the Schuchert Gletscher in North-East Greenland. J. Glaciol. 4, 817-818.

Kupsch, W. O. 1962: Ice-thrust ridges in western Canada. $J$. Geol. 70, 582-594.

Moran, S. R. 1971: Glacitectonic structures in drift. In Goldthwait, R. P. (edit.) Till, a symposium. Columbus: Ohio State University, pp. 129-149.

Petersen, K. Strand 1978: Applications of glacitectonic analysis in the geological mapping of Denmark. Danm. geol. Unders., Arbog 1977, pp. 53-61.

Weidick, A. 1968: Observations on some Holocene glacier fluctuations in West Greenland. Meddr Gronland 165, 3, 202 pp. 